\title{
Low Cost Carriers in the Middle East and North Africa (MENA) region: Emergence and barriers to development
}

\author{
Saeid Joshan ${ }^{1}$, Sven Maertens ${ }^{2 *}$
}

*) Corresponding author

1) Paderborn University, Paderborn, Germany, saeid.joshan@gmail.com

2) German Aerospace Center, Linder Höhe, 51147 Cologne, Germany, sven.maertens@dlr.de

\begin{abstract}
This paper investigates the development of low cost carriers (LCCS) in the Middle East and North Africa (MENA) region from a broader perspective. We use passenger volume data at the airline and flight segment levels to illustrate the development of LCCs in the region; we conduct a structured comparison of the actual business model characteristics of the MENA-based LCCS to assess their adherence to the archetypical LCC business model; and we compile the key barriers to LCC growth in MENA from the literature.

We find that the overall market share of LCCs in MENA is still below the world average - despite high growth in recent years. The presence of LCCs varies considerably between MENA countries and route groups. The more upscale, "Jetblue"-style business model, where passengers benefit from additional, complementary services or product characteristics, prevails. Political tensions, adverse regulations and lower levels of liberalization compared to Europe or North America negatively affect LCC development in many MENA countries. While low middle-class proportions appear to be a challenge for low cost business models, Asian diaspora and tourism - from beach holidays to pilgrimage - seem to induce additional demand.
\end{abstract}

Keywords: Air Transport Development, Middle East, North Africa, Low Cost Carrier 


\section{Introduction}

Despite political tensions throughout the region, up to armed conflicts, air transport in the Middle East and North Africa (MENA) region has experienced rapid growth over the last decades. This development has mainly been driven by the global expansion of Emirates and other carriers from the Persian Gulf region (in the following referred to as "Gulf"). In contrast, the game-changing low cost carrier (LCC) business model, which had first appeared in the USA in the 1970s and in Europe in the 1990s, was introduced in the MENA region relatively late. Complementing a limited number of earlier works (e.g., Schlumberger and Weisskopf, 2014, and Morrison and Mason, 2016), we provide an updated review and discussion of the development and business model characteristics of LCCS in the MENA region.

Largely in line with Morrison and Mason (2016) or Adler and Hashai (2005) ${ }^{1}$, we define MENA as a transcontinental region which - from West to East - consists of (Fig. 1):

- North Africa (Algeria, Egypt, Libya, Morocco, Tunisia),

- the Levant (Israel, Jordan, Lebanon, the Palestinian territories, Syria),

- the Arabian Peninsula (Bahrain, Kuwait, Oman, Qatar, Saudi Arabia, United Arab Emirates (UAE), Yemen),

- Mesopotamia (Iraq) and

- Persia (Iran).

\footnotetext{
${ }^{1}$ Unlike Morrison and Mason (2016), Adler and Hashai (2005) also regard Turkey and Sudan as part of MENA.
} 


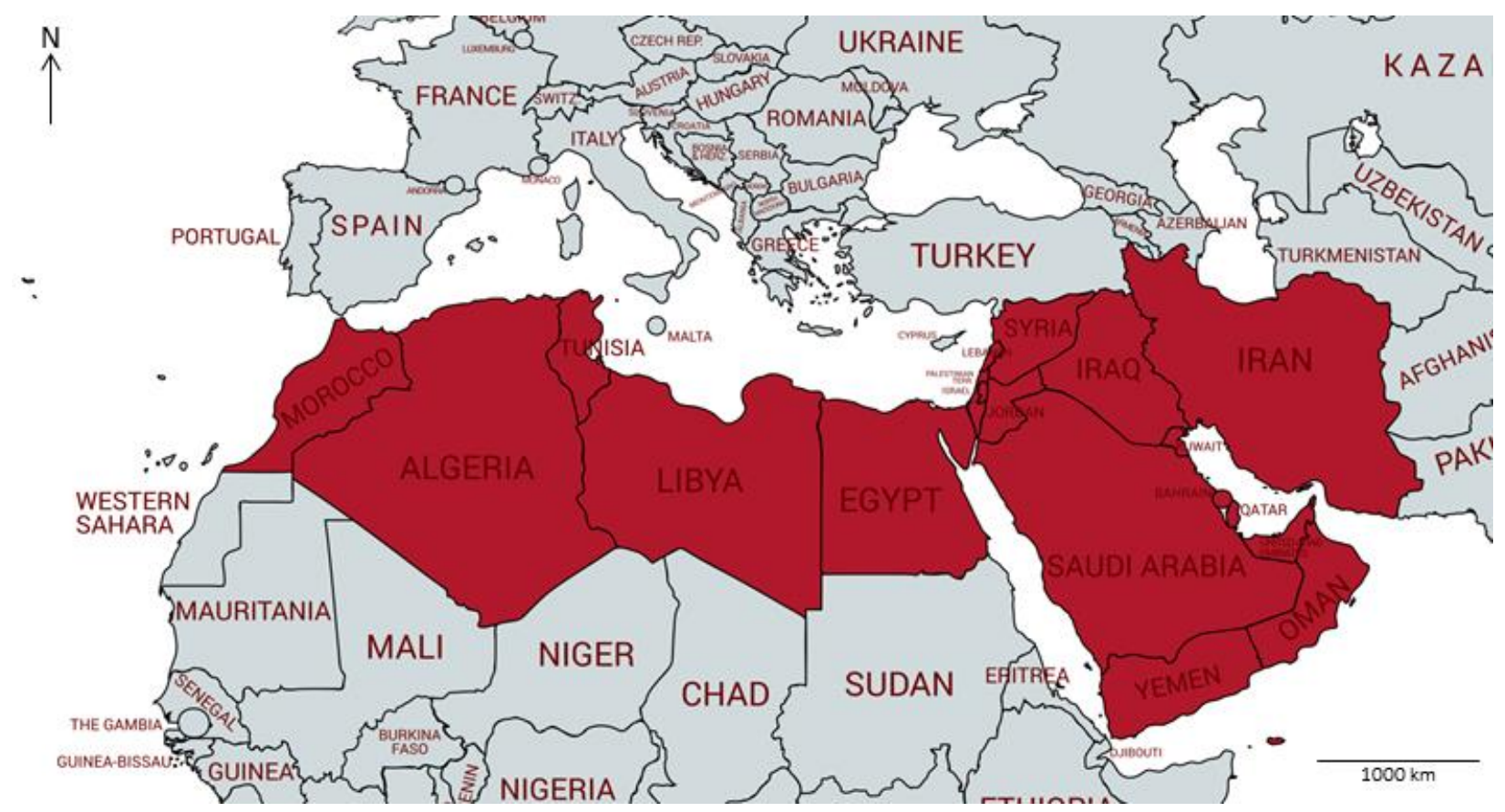

Fig. 1. MENA states (created with mapchart.net).

More precisely, this paper addresses the following issues:

\section{a) How has low cost air travel in the MENA region developed over the past years?}

The literature contains only few existing and partly outdated studies on LCC development in the MENA region. Alkaabi (2014) identified major carriers and markets in Middle-Eastern air transport with a focus on the year 2011; LCCs were, however, only mentioned briefly. Morrison and Mason (2016) reported double-digit average annual passenger increases for the period 2010-2015 for Flydubai (CAGR: 60.5\%), Air Arabia (10.9\%) and FlyNAS (23.3\%), while Kuwait-based Jazeera Airways stagnated (1.5\%). The authors did not include smaller carriers like FlyEgypt or Air Cairo in their analysis. For two reasons, we assume both traffic volumes and market shares of LCC in the region to have grown in recent years: First, one could observe new market entries of airlines like Flyadeal (Saudi Arabia) or Salam Air (Oman); and second, the growth rates of the big full service network carriers (FSNC) Emirates, Qatar Airways and Etihad Airways have slowed down.

\section{b) How "low cost" are the MENA-based LCC?}

Some 20 years ago, the differences between LCC and the FSNC, in the US also known as legacy carriers (Neal and Kassens-Noor, 2011), were still clearly visible. While the latter 
served primary airports and offered their passengers fares that included amenities like free checked luggage and catering, the former introduced a game-changing philosophy which focused on cheap point-to-point flights from secondary airports without any "extras" (Graf, 2005; Kachaner et al., 2011). In recent times, however, it has become increasingly difficult to differentiate between these archetypical business models: Many LCC have introduced features previously known from FSNC, like seat reservations, indirect flights or bundled allin fares, while FSNC came up with reduced seat pitch and paid-for inflight meals and drinks. While the literature contains a number of papers on this "hybridization process" (e.g., Klophaus et al., 2012; Vidović et al., 2013), the particular situation in the MENA region was only dealt with by Morrison/Mason (2016) who identified a number of differences (e.g. with regard to aircraft utilization, cabin layout and luggage/catering) between the MENA-based LCCs Flydubai, Air Arabia, FlyNAS and Jazeera Airways and their European counterparts.

\section{c) What are the key barriers for LCC in the MENA region?}

Unlike, e.g., most of Europe, the MENA region is not harmonized in the political or economic sense and various, and often armed conflicts have been dominating the political landscape for decades. This is supposed to contradict the growth of LCC as this business model best requires liberalized and deregulated regulatory frameworks to be able to operate flexibly and at low unit cost (e.g., Schlumberger and Weisskopf, 2014). We refer to the literature to compile key barriers to the growth of LCC in the MENA region.

The paper is structured as follows: After a literature review in Section 2, Section 3 illustrates the development of the LCCS in the MENA region based on airline-, country- and route-groupspecific passenger volume data. Also in comparison to EasyJet, Ryanair and Wizz Air, Section 4

assesses the key business model characteristics of the MENA-based LCCs. Finally, Section 5 compiles and discusses barriers to the development of LCCs in the MENA region. Section 6 concludes and suggests areas for further research.

\section{Literature}

2.1 Low cost carriers: Business model, geographical coverage and hybridization 
Much of the earlier work on LCCs dealt with the architecture of the low cost airline business model (e.g., Lawton, 2002; Forsyth, 2003; Graf, 2005), or with deregulated regulatory frameworks in key markets like the USA and Europe, which enabled the market entry of LCCS (e.g., Goetz and Vowles, 2009). To minimize cost, the archetypical LCC operates a uniform, single-class fleet on point-to-point routes from smaller airports. Avoiding intermediaries like travel agencies, it sells its capacity directly (in the early days by phone and now online) and applies a simple, one-way based pricing scheme in which fares rise the closer the departure gets. LCCs avoid frills like free catering, lounge access, or frequent flyer programmes. Instead, they generate ancillary revenues in offering à la carte add-ons, such as checked baggage or priority boarding. You get what you pay for!

Other work assessed the development of the business model in terms of geographical coverage or market shares. Dobruszkes (2013) observed an increase in the intra-European seat market share of LCCs from just 5\% in the year 2000 to 31\% in 2012, as well as a network extension to new and sometimes more remote destinations like in Eastern Europe, North Africa and the Canary Islands, which resulted in increasing average stage lengths.

The literature further features increasing research on the hybridization of the LCC and classical network airline business models. While some LCCs have started to implement product features known from the traditional network carriers, from seat reservation over different fare classes to even long haul routes, many FSNCs have revised their products in a way more typical for LCCS (introduction of basic fares without free luggage, elimination of free inflight services...). Key papers on this hybridization trend of the LCC business model include Francis et al. (2007), Mason and Morrison (2008), or Fageda et al. (2015). One of the earliest papers on the LCC business model hybridization is from Alamdari and Fagan (2005). Using a scoring approach for 17 product and operational features of the LCC business model, the authors investigated how the actual business models of ten established US and European LCCs had been modified, and if this had any impact on their financial performance. Applying the Spearman's rank correlation tool, they found a good agreement to the proposition that high adherence to the low cost business model is linked with higher operating margins. 
Another, more recent approach to classify LCC in the hybridization context was taken by Klophaus et al. (2012) who applied an index based on the individual fulfillment of archetypical "LCC criteria" to a group of European airlines widely perceived as LCCs. The authors found that already at that time, only Ryanair, Wizz Air and three other European carriers could still be labeled as pure LCCS, while others had turned into "hybrid carriers with dominant LCC characteristics", "hybrid carriers with dominant full service airline characteristics" or even "full service airlines". In a similar study for the US market, Lohmann and Koo (2013) showed that the ongoing process of hybridization made it increasingly difficult to attribute airlines to predefined, discrete business models.

Work on new markets for LCCs includes Taumoepeau et al. (2017), who analyzed the emergence and impacts of, as well as the barriers to low cost air travel in the Oceania/Pacific region; or Zhang et al. (2008), who assessed the impact of air transport regulations and other frameworks on LCC development. For instance, the authors found that a lack of secondary, low cost airports affected the performance of the LCCs in Asia. Dobruszkes and Wang (2019) assessed the scope for LCCS in not fully deregulated regimes. They found that low cost carriers like Spring Airlines in China lack free access to the market as trunk routes are still protected to some extent in favor of the large FSNCs.

\subsection{Air transport in the MENA region}

Despite intense coverage in the travel trade press, academic work on the air transport market in the Middle East region is still relatively scarce (Dresner et al., 2015) and usually focuses on the development, strategy and impacts of the Gulf-based hub carriers Emirates, Qatar Airways and Etihad Airways. In a relatively early paper, Vespermann et al. (2008) summarized the key success factors of the Gulf carriers: a strategic location between Europe and Asia and enormous investments in fleets, product quality and airport infrastructures in order to redirect indirect traffic between Europe and Asia to the Gulf hubs.

As a consequence, in a wrap-up of the historic development of the air transport market in the Gulf region, Hooper et al. (2011) identified a "principal axis shift" as the region had developed from an intermediate, stop-over point on the East-West corridor to a "central place" in today's 
trade and travel flows. From a broader perspective, Alkaabi (2014) looked at key characteristics and developments of air transport sector in the Middle East with a focus on the Gulf Cooperation Council (GCC) member states Bahrain, Qatar, Kuwait, Oman, Saudi Arabia and UAE, and on the "Big Three" FSNC Emirates, Qatar Airways and Etihad as well as Saudi Arabian Airlines. The author identified cost reduction (stemming from young fleets, low labor costs and tax-free environments), unrestricted provision of airport infrastructures, liberal air service agreements and integrated expansion plans for both the aviation and travel and trade sectors as key strategies of these airlines and their public owners. In addition, the authors showed that high service levels of the Gulf airlines both for the economy and premium class passengers go hand in hand with modern marketing campaigns and sponsoring approaches to increase public perception. Emirates use massive sponsorship activities as a key tool to increase brand awareness, with a focus on various sports. This was also reported by O Connell (2011).

A small number of papers deal with the competitive impact of the use of six-freedom traffic rights by Gulf carriers on established carriers and on other countries. For the Germany-Asia axis, and here especially from secondary airports in Germany to Northeast Asia, Grimme (2011) suggested that routings via the Gulf were usually not a perfect substitute for time-sensitive passengers. This may explain why, in the period 1998-2008, incumbents like Lufthansa had not lost transfer passengers although Emirates could gain market shares. Based on a case study approach for Lufthansa, Vespermann et al. (2008) had come to a similar conclusion. For the US market, Dresner et al. (2015) used data obtained from the U.S. Department of Transportation to empirically assess the effects of Gulf carrier competition on U.S. carriers' passenger volumes and fares in international route markets. Unlike Grimme's observations for Germany, the authors could observe small but significant traffic (and fare) reductions for U.S. carriers on routings between the U.S. and Africa, Asia, Australia and Europe.

De Wit (2014) questioned protectionist measures in Europe as a reaction to the growth of the Gulf airlines. He argued that not an unlevel playing field but the location of the Gulf hubs were the key competitive advantage for these airlines, as they can operate homogenous fleets of wide-body long-haul aircraft from and to their hourglass hubs while their European 
counterparts have to employ much smaller and more costly aircraft to feed their hinterland hubs.

\subsection{Low cost carriers in the MENA region}

Papers on low cost carriers in the MENA region are scarce. Alkaabi (2014) provided an overview of Middle East air transport, but focused very much on the FSNC and regulatory and political issues, while LCCs were only briefly mentioned. The most comprehensive paper here comes from Morrison and Mason (2016) who assessed socio-economic indicators in the region and argued that there should be additional potential for low cost air travel in, e.g., Iran and Saudi Arabia, while other countries in the MENA region still face challenges from insufficient regional liberalization. The authors also compared four MENA-based LCCs to their counterparts in Europe and found that the business models deviate significantly.

As most of the data used by both Alkaabi (2014) and Morrison and Mason (2016) are outdated from today's perspective, this paper aims at providing additional and more up to date insight into the current status of LCCs in the MENA region, especially since other papers on low cost air travel in the MENA region mainly look at more specific aspects like the sector's effects on inbound tourism in Saudi Arabia (Alsumairi and Tsui, 2017). Using Box-Jenkins SARIMA-X forecasting models, the authors assessed to what extent Saudi Arabia's tourism demand is impacted by the presence of LCCs. They found that increases in airline capacity, e.g. from LCCs, religious travel and airline competition yield in increasing international tourist arrivals to Saudi Arabia. Another contribution that - partly - looked at the development of LCCs in the Middle East is from Bowen (2019). He refers to these airlines as "shorter superconnectors" which add connectivity to the long haul flight supply provided by the "Gulf "superconnectors" (Emirates Airline, Etihad Airways, and Qatar Airways) and Turkish Airlines" in providing capacity for, e.g., guest workers from South Asia and for tourists to and from Europe. The author further observed only minimal cooperation between the superconnectors and LCCs but the potential for greater collaboration in the future. He also argued that "war and political unrest in several parts of the region have inhibited budget airlines and sometimes cleared the skies altogether" but expects the regional LCCs to cultivate new markets once "a modicum of peace is attained". 
A comprehensive look at the potential, drivers and impacts of LCCs in developing countries was provided in a study by Schlumberger and Weisskopf (2014) on behalf of the World Bank. The authors developed a framework for the transferability of the LCC business model to developing countries. The indicators they considered include demand, air transport infrastructure, degrees of air transport liberalization, safety and security levels, politics and distribution. Regarding demand, they argued that market entrance and initial demand generation is a critical and important phase when establishing an airline, especially for LCCs. In developing countries, increases in the share of middle-class people seem to benefit the emergence of LCCs. Another important element for establishing a LCC is access to deregulated markets. However, air transport in many developing countries is remarkably regulated. The authors finally argue that, although the LCC market share is increasing in several developing countries, there are still some major problems to consider, and they prioritize passenger demand, air transport liberalization and good governance elements as the ones of the highest importance. The MENA region is only tackled partly in this study, which however contains a market entry model for LCCs in Egypt.

One of the few other papers that - at least partly - deal with LCCs in Africa is from Njoya (2016) who assessed recent developments in the African aviation sector with a focus on the implementation of the Yamoussoukro Decision (YD) from 1999, which aimed at gradual liberalization of intra-African air transport. The author found that LCCs - which try to avoid traffic rights issues in setting up subsidiaries - represented a high share of regional traffic growth in Africa. Pirie (2014) also looked at low cost carrier performance in Africa but focused, as Njoya (2016), on carriers from Sub-Sahara Africa. The same applies to Amankwah-Amoah and Debrah (2009) who developed a framework for analyzing the emergence and improving the performance of LCC in Africa consisting of internal (e.g. decision-maker characteristics, distribution channel and cost management capabilities...) and external (e.g. market conditions, application of the Yamoussoukro Declaration...) drivers.

\section{Air Transport and LCC development in the Region}

\subsection{Overview}


According to IATA (2018b), 3.3\% of all employment in the MENA region stems from the aviation sector which represents 2.3 million jobs and $\$ 130$ billion of the region's GDP. It is expected that, over the next 20 years, the number of passengers will rise by $4.3 \%$ per year. Over the last 30 years, following the emergence of Emirates in 1985, legacy carriers from the Gulf region have introduced and increased their unique long haul, hub and spoke business model, facilitated by high investments mainly from the oil-rich Governments. Today, Emirates, Qatar Airways and Etihad Airways offer a global route network from their Gulf hubs and target two markets: (a) direct access from and to the Gulf region, boosting economic and tourism, (b) provision of onestop connectivity via the Gulf between almost all world regions.

The geography of the air transport sector differs significantly within the MENA region. Geographically larger countries like Iran or Saudi-Arabia are characterized by dense domestic networks in addition to international routes, while smaller countries like Jordan, Lebanon or the UAE and Qatar are almost exclusively characterized by international routes.

We use available air transport statistics to assess the development of LCCs in the MENA region from different angles: Section 3.2 introduces our data source and Section 3.3 identifies LCCs based in MENA and those flying from outside into MENA; Section 3.4 compares the development of LCC and non-LCC passenger numbers in MENA at aggregated and individual country levels; Section 3.5 looks at the development of the route structure of MENA-based LCCs, and Section 3.6 finally compares the relevance of LCCS on different spatial route types.

\subsection{Data source}

Access to air transport output data at the route and airline levels is essential to assessing the development of the regional LCCs. However, passenger numbers at the airline level are usually not available publicly, except for the U.S. Bureau of Transportation Statistics' $10 \%$ sample of airline tickets sold (Airline Origin and Destination Survey DB1B) ${ }^{2}$ which only covers the USA. The payable Sabre Market Intelligence (MI) database provides passenger numbers at different levels as monthly aggregates (Sabre, 2014). Its main sources of data are MIDT (Marketing Information Data Tapes) booking data from computer reservation systems (CRS) and additional

\footnotetext{
${ }^{2}$ https://www.transtats.bts.gov/Databaselnfo.asp?DB_ID=125.
} 
sources, e.g. from national statistical offices, supplemented by estimates for direct sales and charters. Maertens (2018) assumes the quality of Sabre's passenger volume data at higher aggregated (country and region) levels to be sufficiently good for, e.g., trend analyses. A random check in a German corporate travel reservation system, conducted in March 2020, has revealed that all of the MENA-based LCCs (except for Flyadeal, Salam Air and FlyEgypt) sell via CRS, which yields reasonable (Sabre MI) data quality.

\subsection{MENA-based LCC and foreign LCC operating into MENA}

The first LCC in MENA, Sharjah-based Air Arabia, emerged in 2003. Today, the region is home to some ten LCCs: three in Egypt, two each in Saudi Arabia and the UAE, and one each in Morocco, Oman and Kuwait (Table 1). The table lists Air Arabia Egypt and Air Arabia Morocco as individual airlines as they operate under Air Operator Certificates issued by Egypt and Morocco, respectively. However, from a customer perspective, they fully appear as Air Arabia.

The largest LCC in the region is Flydubai which accounted for 8 Million passengers departing from MENA airports in 2018, followed by Air Arabia (7.9 Million including all subsidiaries) and Flynas from Saudi Arabia (7.3 Million). Flyadeal (from Saudi-Arabia) and Jazeera Airways (from Kuwait) both report about two Million passengers, while the remaining ones are much smaller.

\section{Table 1}

Year of foundation and Country of origin of MENA-based LCCs.

Sources: Airline websites, Sabre MI

\begin{tabular}{|l|l|l|r|}
\hline MENA-based LCC & Year of Foundation & Origin Country & Departing pax from MENA (2018) \\
\hline Air Arabia & 2003 & United Arab Emirates & $6,333,408$ \\
\hline Air Arabia Egypt & 2009 & Egypt & 500,121 \\
\hline Air Arabia Maroc & 2009 & Morocco & $1,032,448$ \\
\hline Air Cairo & 2003 & Egypt & 956,092 \\
\hline Flyadeal & 2017 & Saudi Arabia & $2,205,166$ \\
\hline Flydubai & 2008 & United Arab Emirates & $8,006,407$ \\
\hline FlyEgypt & 2014 & Egypt & 288,408 \\
\hline Flynas & 2007 & Saudi Arabia & $7,287,612$ \\
\hline Jazeera Airways & 2004 & Kuwait & $2,010,296$ \\
\hline
\end{tabular}


In addition, Table 2 shows the largest foreign LCCs in the MENA region. Basically, these carriers split into three groups: European LCCs (Ryanair, Transavia, EasyJet, Vueling, Smartwings) flying from Europe into Morocco and other leisure places in MENA; Indian LCC (and Lion Air from Indonesia) focusing on flights for migrant workers between the Gulf and South (East) Asia, and Pegasus connecting its Istanbul hub with a large number of MENA airports.

Table 2

Largest non-MENA LCC operating from MENA (departing passengers, 2018).

Source: Sabre MI

\begin{tabular}{|l|l|r|}
\hline LCC & Origin Country & Departing pax from MENA (2018) \\
\hline Ryanair & Ireland & $2,082,782$ \\
\hline Air India Express & India & $1,770,813$ \\
\hline Indigo & India & $1,508,972$ \\
\hline Pegasus Hava Tasimaciligi & Turkey & $1,092,002$ \\
\hline Transavia France & France & $1,031,657$ \\
\hline Easyjet & UK & 915,152 \\
\hline Vueling Airlines & Spain & 360,841 \\
\hline Smartwings & Czech Republic & 319,551 \\
\hline Transavia Airlines & Netherlands & 240,746 \\
\hline Lion Airlines & Indonesia & 147,977 \\
\hline
\end{tabular}

\subsection{Development of LCC and non-LCC passenger numbers in MENA}

Fig. 2 depicts the air transport development in the MENA region. Over the period 2010 to 2018, the number of departing passengers increased by 62\%, from almost 140 Million to 225 Million. LCCs represent a small but growing portion of the total passenger numbers, with market shares of 10\% (13 Million) in 2010 and 16\% (35.8 Million) in 2018, respectively. 


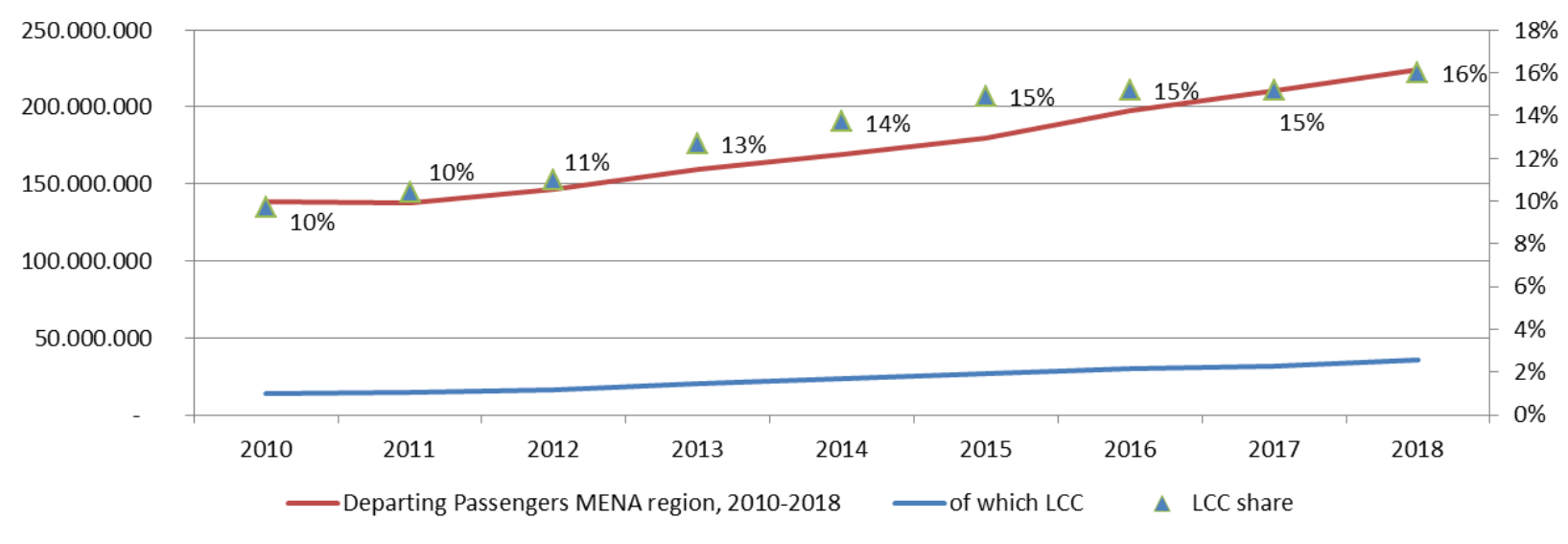

Fig. 2. Departing passengers, MENA region (Source: Sabre MI).

As Fig. 3 and 4 show, total passenger growth and growth and presence of LCC vary between the countries. Out of the "larger" aviation markets in the region (UAE, Saudi-Arabia, Qatar, Iran, Egypt, Israel, Morocco), countries with continuous air passenger growth are Saudi Arabia and, at a much smaller scale, Israel and Morocco (Fig. 3). The UAE and Qatar have stagnated since 2016/2017, which may be explained with Etihad's capacity reductions at Abu Dhabi airport, with runway reworks and resulting capacity reductions at Dubai airport, and with the ban for Qatar-bound flights in the UAE, Saudi Arabia, Bahrain and Egypt as a result of political tensions. Iran reported a downward period until 2014, followed by an upward period, which was supposed to be caused by the (temporary) lifting of sanctions following the nuclear deal in 2015. Despite strong growth in 2017 and 2018, Egypt still ended up 4\% below 2010 levels, the year preceding the Arab spring tensions. Annex 1 contains the total passenger development in detail for each MENA state.

In all of the larger markets, LCCs (indicated by the black columns in Fig. 3) have grown by $100 \%$ or more, except for Qatar, which has lost the LCC supply from other Gulf states, and Egypt for the above-mentioned reason. In Iran, low cost travel is still very much negligible, which may be caused by sanctions against the country which, e.g., make it virtually impossible for the country's carriers to source new aircraft or to accept credit cards. The UAE and Saudi Arabia are not only the largest regional air travel markets in general but also for LCCs. Annex 2 contains the low cost passenger numbers in detail for each MENA state. 


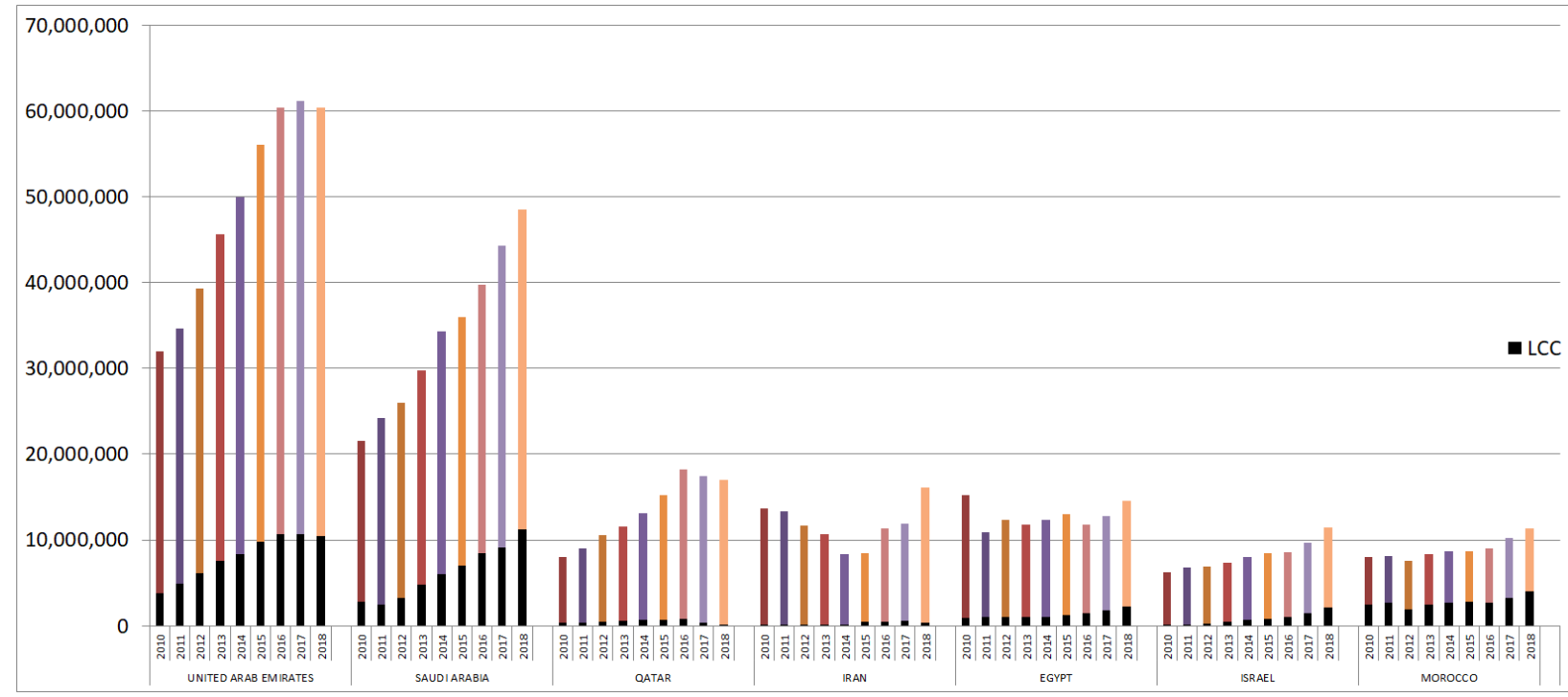

Fig. 3. Departing passengers (total and LCC), larger aviation markets (Source: Sabre MI).

In the smaller MENA aviation markets (Figure 4), Oman (+142\% in passenger numbers between 2010 and 2018), Kuwait (+67\%), Algeria (+62\%) and - from a much smaller basis - post-war Iraq $(+634 \%)$ were the main growth drivers. Tunisia (+3\%) and Bahrain $(-9 \%)$ seem to have not yet fully recovered from the Arab Spring tensions, while massive declines for Libya (-65\%), Syria (85\%) and Yemen (-99\%) reflect the ongoing civil war and terror situation. Air traffic in Palestine is suspended. Kuwait is the largest location for LCCs among the smaller aviation markets, as Jazeera Airways is based and continuously growing there. Oman, Jordan, Bahrain, and Iraq also show significant growth, albeit at a much smaller scale.

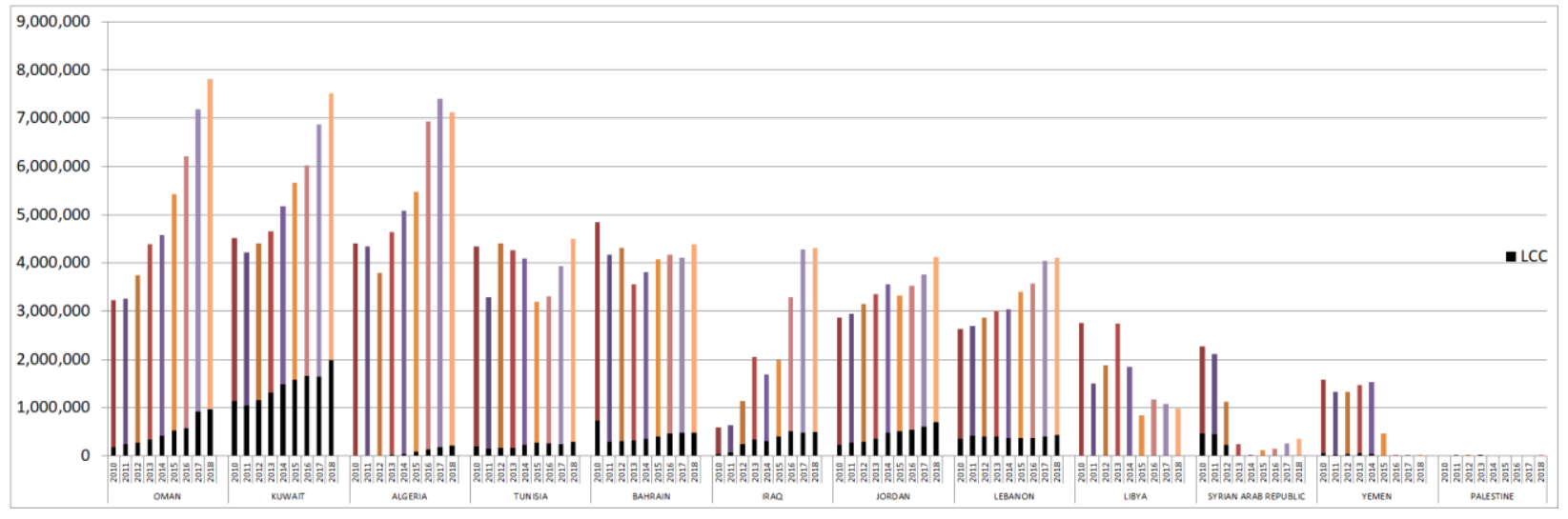

Fig. 4. Departing passengers (total and LCC),smaller aviation markets (Source: Sabre MI). 
MENA-wide, Table 3 compares the market growth between 2010 and 2018 on routes on which LCCs are present in 2018 ("LCC markets") with the market growth achieved on routes without competition from LCCS ("non-LCC markets"). It shows that, on average, markets with LCC presence have grown stronger (+72\%) than those without supply from LCCs $(+40 \%)$.

Table 3

Market stimulation by LCCs, MENA Region, 2018 vs. 2010.

Source: Sabre MI.

\begin{tabular}{|l|l|l|l|}
\hline Year & $\mathbf{2 0 1 0}$ & $\mathbf{2 0 1 8}$ & Growth 2010-2018 \\
\hline Departing pax all markets & 138.676 .232 & 224.600 .380 & $62 \%$ \\
\hline Departing pax LCC markets & 95.981 .715 & 164.618 .191 & $72 \%$ \\
\hline Departing pax non-LCC markets & 42.694 .517 & 59.982 .189 & $40 \%$ \\
\hline
\end{tabular}

3.5 Development of routes by MENA-based LCC

The number of city-pairs (only considering routes with more than 500 passengers per month in each direction, to eliminate data errors) operated by MENA-based LCC has increased by $131 \%$ from 146 in September 2010 to 337 in September 2018. As Fig. 5 shows, activities in 2010 were concentrated on flights between Europe and Morocco, on the one hand, and on routes between the Gulf region and the Levant and the Indian Subcontinent, on the other hand. In 2018, the picture is different (Fig. 6), with new services from the Gulf and the Levant to Europe, including Eastern Europe, and an increased number of routes between the Gulf region and the CIS states, Sub-Saharan Africa and South Asia. 


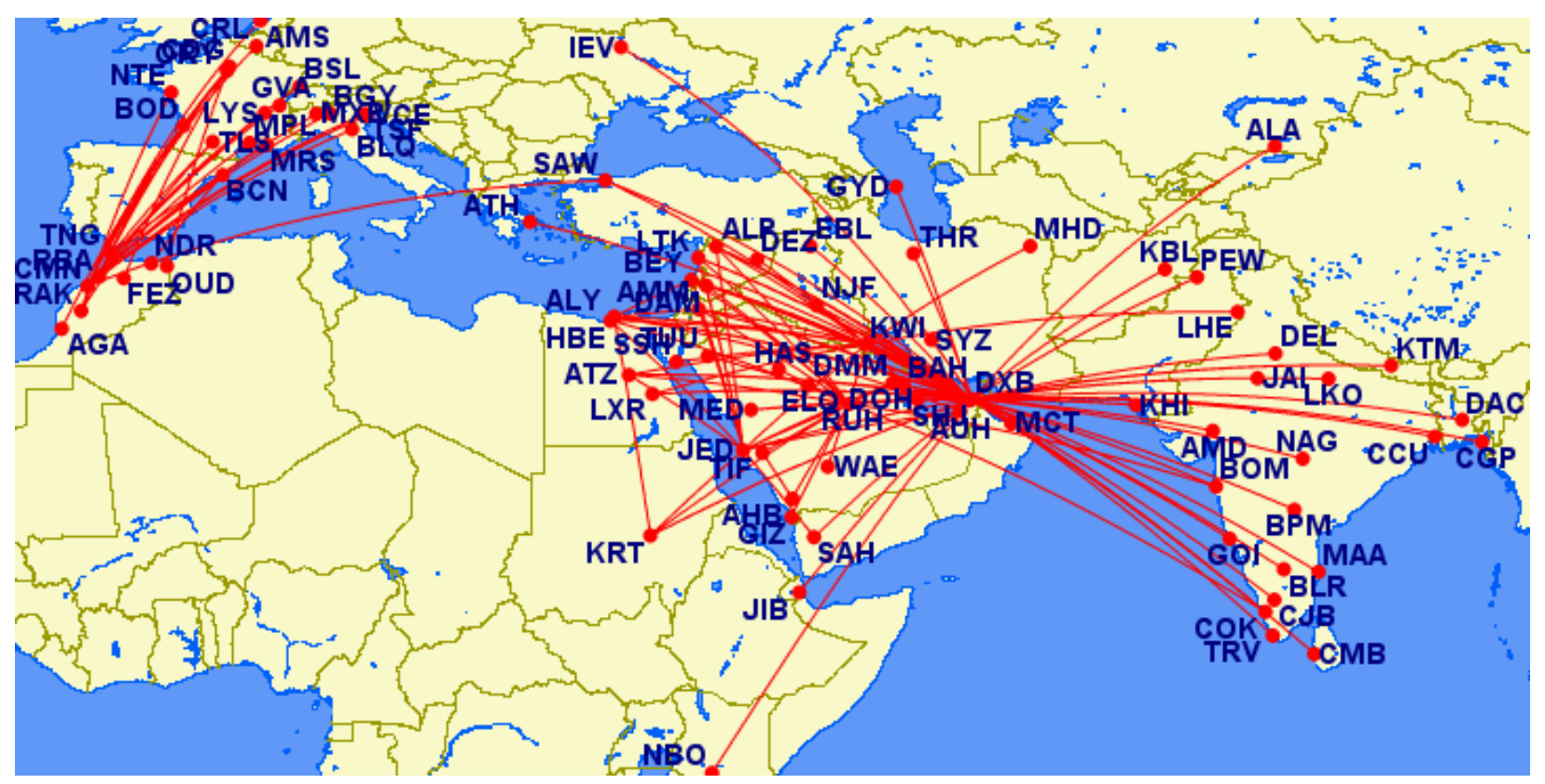

Fig. 5. Route network of MENA-based LCC (September 2010).

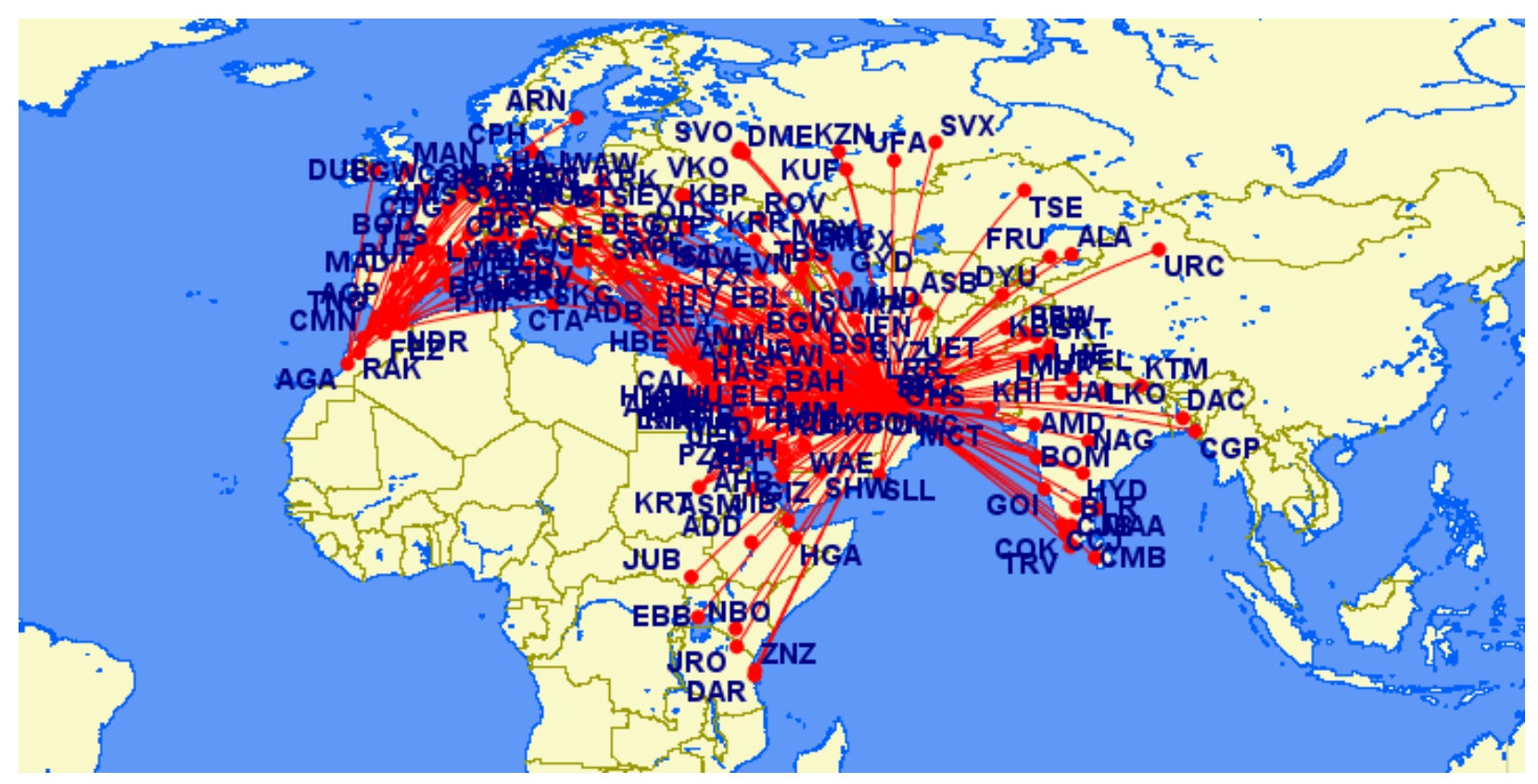

Fig. 6. Route network of MENA-based LCC (September 2018).

\subsection{LCC-relevance by route type}

Finally, we compare the development of total passenger volumes, and of the passengers generated by MENA- and non-MENA based LCCs, at the spatial, region-pair level (Table 4). The results indicate that the market share of LCC in the year 2018 was largest on routes within 
MENA (21\%), followed by routes to Europe (16.9\%). This is not unexpected as a) the LCC business model is mainly relevant on short- and medium haul routes and b) both Air Arabia and European LCC have massively inaugurated routes between Morocco and the EU. LCC supply on the axis MENA-Asia, where LCC held a market share of $7 \%$, can mainly be observed on routes from and to South Asia (India, Pakistan...), catering for the needs of guest workers and their families.

\section{Table 4}

Total and LCC departing passenger numbers by route group, MENA Region, 2018 vs. 2010.

Source: Sabre MI.

\begin{tabular}{|c|c|c|c|c|}
\hline Year & & 2010 & & \\
\hline Carrier Type & All pax & LCC pax & Share LCC & \\
\hline $\begin{array}{l}\text { Departing passengers } \\
\text { MENA (all routes) }\end{array}$ & $138,676,232$ & $13,912,110$ & $10.0 \%$ & \\
\hline MENA-Europe & $36,387,020$ & $3,100,318$ & $8.5 \%$ & \\
\hline MENA-Asia/Pacific & $22,513,213$ & $1,309,428$ & $6 \%$ & \\
\hline MENA-MENA & $72,987,864$ & $9,282,763$ & $12.7 \%$ & \\
\hline MENA-Americas & $2,933,059$ & - & $0.0 \%$ & \\
\hline MENA-Africa & $3,855,034$ & 219,599 & $5.7 \%$ & \\
\hline Year & & 2018 & & \\
\hline Carrier Type & All pax & LCC pax & Share LCC & $\begin{array}{l}\text { Change (pps) } \\
2018 / 2010\end{array}$ \\
\hline $\begin{array}{l}\text { Departing passengers } \\
\text { MENA (all routes) }\end{array}$ & $224,600,380$ & $36,218,151$ & $16.1 \%$ & $6.1 \%$ \\
\hline MENA-Europe & $58,752,016$ & $9,920,455$ & $16.9 \%$ & $8.4 \%$ \\
\hline MENA-Asia/Pacific & $45,723,412$ & $3,213,777$ & $7 \%$ & $1.2 \%$ \\
\hline MENA-MENA & $107,015,725$ & $22,423,062$ & $21.0 \%$ & $8.2 \%$ \\
\hline MENA-Americas & $5,356,572$ & 28 & $0.0 \%$ & $0.0 \%$ \\
\hline MENA-Africa & $7,752,537$ & 660,819 & $8.5 \%$ & $2.8 \%$ \\
\hline
\end{tabular}

\section{LCC business models in the MENA: Pure or Hybrid?}

As already considered in Section 2, the low-cost business model has been continuously redeveloped over the past years. While some airlines remain close to the original Southwest or to some respect even more fundamental - Ryanair business models, others introduced 
additional features or went hybrid. Schlumberger and Weisskopf (2014) introduced a typology of three different business models for LCCs:

1) The "purist model" for which Ryanair, Wizz Air or US-based Spirit are known best, with a consequent focus on cost reduction, point-to-point services and the generation of ancillary revenues;

2) The more upscale "Southwest model", which contains a higher service level (in the case of Southwest refreshments and peanuts; "The peanut airline") aboard, more luggage allowance, a wider seat pitch and sometimes even online connections;

3) The "JetBlue model" which can be classified as hybrid as such airlines mostly use the primary airport, offer more frills aboard or even introduce business class cabins. Some airlines from this group also maintain codeshare agreements and/or offer connections with FSNCs, like, e.g., Vueling from Spain or Eurowings from Germany.

To compare the business models of the LCCS in the MENA region, we score the carriers' adherence to key features and characteristics of LCCs as discussed in the literature (e.g., Schlumberger and Weisskopf, 2014; Morrison and Mason, 2016; Klophaus et al., 2012) and use the "big three" European LCCs as "benchmarks". This approach is similar to the scoring approach by Alamdari and Fagan (2005), but considers only 13 instead of 17 criteria:

- "point-to-point networks without online connections" instead of the features "routing", "allow connections", and "through-fares";

- no consideration of the feature "seat assignments" as this is today - unlike 2005 offered by all carriers;

- no use of the criterion "designated cargo" due to a lack of reliable information on this;

- introduction of the LCC-criterion "No alliance membership or interlining" instead of "codeshares" to account for the fact that interlining between LCC and other airlines does not necessarily require actual code-sharing.

Based on current information from, e.g., airline websites, Table 5 shows the results of our comparison. 
Table 5

Adherence of MENA-based LCC to the LCC business model

Sources: Various.

\begin{tabular}{|c|c|c|c|c|c|c|c|c|c|c|c|}
\hline LCC Characteristics & Flydubai & Air Ara bia & Flynas & Flyadeal & $\begin{array}{l}\text { Jazeera } \\
\text { Airways }\end{array}$ & SalamAir & Air Cairo & FlyEgypt & Ryanair & Easylet & Wizz Air \\
\hline $\begin{array}{l}\text { No Free Meals } \\
\text { Onboard** }\end{array}$ & 1 & 1 & 1 & 1 & 1 & 1 & 0 & 1 & 1 & 1 & 1 \\
\hline $\begin{array}{l}\text { No Free Checked } \\
\text { Baggages** }\end{array}$ & 1 & 1 & 1 & 1 & 1 & 1 & 0 & 0 & 1 & 1 & 1 \\
\hline $\begin{array}{l}\text { Only Small Hand } \\
\text { Luggage* included** }\end{array}$ & 0 & 0 & 0 & 0 & 0 & 0 & 0 & 0 & 1 & 0 & 1 \\
\hline $\begin{array}{l}\text { No In-flight } \\
\text { Entertainment/ PTVs }\end{array}$ & 0 & 1 & 1 & 1 & 0 & 1 & 1 & 1 & 1 & 1 & 1 \\
\hline $\begin{array}{l}\text { Point-to-Point Network } \\
\text { without on-line } \\
\text { connections }\end{array}$ & 0 & 0 & 1 & 1 & 0 & 0 & 1 & 1 & 1 & 1 & 1 \\
\hline $\begin{array}{l}\text { Dominant Usage of } \\
\text { Secondary } \\
\text { Airports or Terminals }\end{array}$ & 1 & $1 * * *$ & 0 & 0 & 1 & 0 & 0 & 0 & 1 & 0 & 1 \\
\hline $\begin{array}{l}\text { Single Aircraft } \\
\text { Type/Family }\end{array}$ & 1 & 1 & 1 & 1 & 1 & 1 & 1 & 1 & 1 & 1 & 1 \\
\hline $\begin{array}{l}\text { Single Service Class } \\
\text { Cabin }\end{array}$ & 0 & 1 & 0 & 1 & 1 & 1 & 1 & 1 & 1 & 1 & 1 \\
\hline $\begin{array}{l}\text { Focus on Online } \\
\text { Distribution }\end{array}$ & 0 & 0 & 0 & 0 & 0 & 0 & 0 & 0 & 1 & 1 & 1 \\
\hline Simple One-way Pricing & 1 & 1 & 1 & 1 & 1 & 1 & 1 & 1 & 1 & 1 & 1 \\
\hline Only One Fare Class & 0 & 0 & 0 & 0 & 0 & 0 & 0 & 0 & 0 & 0 & 0 \\
\hline $\begin{array}{l}\text { No Frequent Flyer } \\
\text { Programme }\end{array}$ & $0 * * * *$ & 0 & 0 & 1 & 0 & 0 & 1 & 1 & 1 & 1 & 1 \\
\hline $\begin{array}{l}\text { No Alliance Membership } \\
\text { or Interlining }\end{array}$ & 0 & 1 & 1 & 1 & 1 & 1 & 1 & 1 & 1 & 1 & 1 \\
\hline $\begin{array}{l}\text { LCC Characteristics } \\
\text { Possession }\end{array}$ & $5 / 13$ & $8 / 13$ & $7 / 13$ & $9 / 13$ & $7 / 13$ & $7 / 13$ & $7 / 13$ & $8 / 13$ & $12 / 13$ & $10 / 13$ & $12 / 13$ \\
\hline $\begin{array}{l}\text { *) Laptop or lady bag size, usu } \\
\text { **) in cheape st fare } \\
* * * \text { *) Sharjah considered to be } \\
* * * *) \text { Emirates Skywards prog }\end{array}$ & $\begin{array}{l}\text { lly not excee } \\
\text { secondary } \\
\text { amme }\end{array}$ & ing $25 \mathrm{~cm} \times 3$ & $\mathrm{~m} \times 20 \mathrm{~cm}$ & 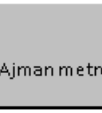 & (1) & & & & & & \\
\hline
\end{tabular}

We count how many of a total of up to 13 "LCC" criteria each carrier fulfills and define a fulfillment degree of $85 \%$ (11 out of 13 ) as required to classify an airline as purist LCC, while $60 \%(8 / 13)$ would be needed for a "Southwest"-style carrier and $40 \%(5 / 13)$ for a hybrid one.

In summary, we find that no MENA-based airline can be referred to as a purist LCC. Three airlines, Flyadeal (9/13), Air Arabia (8/13) and FlyEgypt (8/13), can be grouped as Southweststyle carriers (8-10 out of 13), while the majority of budget carriers in the MENA region follows a hybrid business model and are, hence more comparable to Jetblue, Eurowings or Vueling than 
to Ryanair, EasyJet or Wizz Air. These airlines are Flynas, Air Cairo, Salam Air, Jazeera Airways (7/13 each) and Flydubai (5/13) (Table 6).

Table 6

Categorization of LCCs in MENA according to their business models.

\begin{tabular}{|l|l|}
\hline LCC Categorization & Applicable LCCs in MENA \\
\hline The Purist Model & --- \\
\hline The Southwest Model & Flyadeal (9/13), Air Arabia (8/13), FlyEgypt (8/13) \\
\hline The JetBlue Model & $\begin{array}{l}\text { Flynas (7/13), Air Cairo (7/13), Salam Air (7/13), } \\
\text { Jazeera Airways (7/13), Flydubai (5/13) }\end{array}$ \\
\hline
\end{tabular}

In the following, we have a more detailed look into the business model characteristics of the MENA-based LCCs. Removing free catering and free checked baggage are among the most original and straightforward characteristics for a LCC, as this is easy to implement and generates large potentials for ancillary revenues. The MENA-based LCCs make no exception here, except for Air Cairo which still offers free meals and free checked baggage to all passengers, even those buying the cheapest economy fares.

Reducing hand luggage allowance is a new strategy of LCCs to generate additional revenues. While, e.g., EasyJet still allows travelers to bring one large piece of hand luggage (trolley) aboard, Ryanair and Wizz Air have restricted hand luggage allowance to one smaller piece - a decision which might help generating additional ancillary revenues as additional or larger hand luggage has to be paid for extra. In the MENA, all LCCs still accept trolley-size hand luggage.

Another feature of LCCs is not to equip its aircraft with in-flight entertainment devices. Key benefits of this are to save license and maintenance costs and to reduce aircraft weight. Flydubai is the only airline in the region providing personal screens for the passengers. Besides, Jazeera Airways offers "Jazeera Screens" which allow passengers to watch pre-selected entertainment programmes on their own devices.

The point-to-point network strategy is another fundamental pillar of the LCC business model. Lordan (2014) and Cento (2009) argue that this network system allows the carriers to maximize 
aircraft utilization and to reduce delays compared to the hub and spoke networks. We acknowledge that Ryanair has started to sell selected indirect connections from 2017 where passengers can be routed via Bergamo, Rome or Porto. However, Klophaus and Fichert (2019) found that the airline did not modify its network or schedules in order to better accommodate transfer passenger flows but just offers transfer opportunities where the schedules "fit". For this reason, we still refer to Ryanair as a point-to-point airline. In MENA, Flydubai, Jazeera Airways, SalamAir and Air Arabia offer on-line connections and use their main airports as hubs, while others operate less concentrated networks and do not focus on transfer passengers.

In the network choice context, the use of secondary airports is another advantage for LCCs as airport charges and handling and taxi times are generally lower. In the case of the MENA LCCs, most carriers focus on primary airports as, in contrast to Europe, remotely located secondary airports hardly exist. However, LCCs do not necessarily have to use secondary airports to save airport-related costs. Instead, they may also use secondary, low-budget terminals, which are sometimes provided by airport operators in order to become more attractive for LCCs. We observe that Flydubai and Jazeera Airways operate from dedicated low cost terminals at Dubai International Airport (DXB) and Kuwait International Airport (KWI), respectively.

Single-aisle fleet standardization and high-density, single-class cabins are other features of LCCS (Boeing, 2018). In the MENA region, as shown in Table 7, most LCCs operate either a single-type aircraft fleet (Flynas, Flyadeal, Air Cairo) or two or three variants of the same aircraft type or family (Flydubai, Jazeera Airways, Salam Air, Air Arabia, FlyEgypt), usually Boeing 737-800/MAX or A320/A321(neo). While most airlines operate their aircraft in an all-economy layout, two carriers (Flydubai, Flynas) also offer dedicated business or premium class cabins: This reduces the overall number of seats and leads to increased average costs per seat - which is not a typical approach for LCC. We further observe that even those airlines which have chosen a single-economy remain below the aircraft-type-specific maximum seating capacity: For example, Salam Air (Y174), Air Cairo (Y174), Jazeera Airways (Y174) and Air Arabia (Y168, Y162, Y174) remain below the 180/186 seat capacity configuration applied by, e.g., EasyJet or Wizz Air on the Airbus 320. Also, Air Arabia operates its A321neo with 215 seats compared to 235 as 
chosen by EasyJet. On its website, Salam Air actively promotes "generous leg space and a comfortable seat pitch" on its fleet. ${ }^{3}$

\section{Table 7}

Fleets and seat configurations of LCCs in MENA.

Sources: Airline websites, seatguru.com.

\begin{tabular}{|c|c|c|c|}
\hline MENA-based LCC & Fleet & Seat Configuration & $\begin{array}{l}\text { All Economy: } \\
\% \text { of aircraft-type specific } \\
\text { maximum seat capacity }\end{array}$ \\
\hline \multirow[t]{3}{*}{ Flydubai } & Boeing 737 MAX 8 & C10Y156 & n.a. \\
\hline & Boeing 737 MAX 9 & C16Y156 & n.a. \\
\hline & Boeing 737-800 & Y189 (V1), C12Y162 (V2) & 100\% / n.a. \\
\hline Flynas & Airbus 320 & C8Y156 & n.a. \\
\hline Jazeera Airways & Airbus 320neo & Y174 & $94 \%$ \\
\hline Flyadeal & Airbus 320 & Y186 & $100 \%$ \\
\hline \multirow[t]{2}{*}{ SalamAir } & Airbus 320 & Y174 & $94 \%$ \\
\hline & Airbus 320neo & Y180 & $97 \%$ \\
\hline \multirow[t]{2}{*}{ Air Arabia } & Airbus 320 & Y168 (V1), Y174 (V2) & $90 \% / 94 \%$ \\
\hline & Airbus 321neo & Y215 & $91 \%$ \\
\hline Air Cairo & Airbus 320 & Y174 & $94 \%$ \\
\hline \multirow[t]{2}{*}{ FlyEgypt } & Boeing 737-700 & Y148 & -- \\
\hline & Boeing 737-800 & Y189 & $100 \%$ \\
\hline \multicolumn{4}{|l|}{ For comparison } \\
\hline Ryanair & Boeing 737-800 & Y189 & $100 \%$ \\
\hline \multirow[t]{3}{*}{ EasyJet } & Airbus 319 & Y156 & -- \\
\hline & Airbus 320 & Y180 (V1), Y186 (V2) & $97 \% / 100 \%$ \\
\hline & Airbus 321neo & 235 & $100 \%$ \\
\hline \multirow[t]{2}{*}{ Wizz Air } & Airbus 320 & Y180 & $97 \%$ \\
\hline & Airbus 321 & Y230 & $100 \%$ \\
\hline
\end{tabular}

\footnotetext{
${ }^{3}$ https://www.salamair.com/en/about-us/our-fleet
} 
The phenomenon of growing internet penetration helped airlines to introduce new sales channels, and LCCS use online sales as a very important cost reducer. Considering the MENA region, we find that no airline seems to exclusively sell online, as all airlines still operate downtown sales offices (Table 8) and/or distribute via CRS/GDS.

One reason for MENA-based LCCS to stick to sales offices may be limited access to cash-less payments in cash economies. According to World Bank data, the global average percentage of citizens above 15 holding a credit card is $19.41 \%$. While this ratio is much higher for most developed countries (e.g. Canada 83\%, Israel 75\%, Norway and Luxembourg 70\%), most MENA states are characterized by a far lower distribution of credit cards: UAE (45\%), Bahrain (30\%), Kuwait (22\%), Saudi-Arabia (16\%), Lebanon (15\%), Iran (9\%; no international credit cards), Tunisia (7\%), Egypt, Algeria, Jordan (3\% each), Iraq and Morocco (2\% each). ${ }^{4}$

\section{Table 8}

Sales offices of MENA-based LCCs.

Sources: Airline websites.

\begin{tabular}{|l|l|}
\hline MENA-based LCC & Number of Sales Offices \\
\hline Air Arabia & 115 offices in 42 countries \\
\hline Air Cairo & 21 offices in 13 countries \\
\hline Flyadeal & No sales offices \\
\hline Flydubai & 85 offices in 46 countries \\
\hline FlyEgypt & 5 offices in 4 countries \\
\hline Flynas & 42 offices in 14 countries \\
\hline Jazeera Airways & No sales offices \\
\hline SalamAir & 16 offices in 12 countries \\
\hline
\end{tabular}

From the late 1980s, traditional airline revenue management systems experienced a noticeable change in their development (Fiig et al., 2009). By virtue of using new forecasting and pricing models, airlines could optimize their revenue streams in introducing different fare classes and dynamic ticket pricing. Moreover, the emergence of LCCs in the air transport industry has caused revolutionary changes in pricing strategies. In Europe, Anjos et al. (2004) argue that

\footnotetext{
${ }^{4}$ https://www.theglobaleconomy.com/rankings/people_with_credit_cards/.
} 
LCCs have caused a massive change in the pricing strategies by bringing in the one-way pricing system to the industry as a profitable low-cost strategy. We observe that MENA-based LCCs make no exception here as they also offer simple one-way fares.

However, most LCCs now depart from the strategy to only offer one fare type at a given time. Instead, it seems increasingly relevant to offer "premium" fares which would include a "bundle" of additional extras which could or could not otherwise be purchased separately, like seat reservation, free checked baggage, priority boarding or relaxed rebooking or cancelation options. We find that this also applied to the MENA-based LCCs.

Frequent flyer programmes (FFP) are an important marketing tool for airlines. Passengers are incentivized by cash-equivalent and non-monetary (status) benefits to fly the same airline or alliance more often, and to pay more, whereby a key role stems from principal-agent issues as the ticket buyer is in many cases, not the person who actually flies and benefits (e.g., Martín et al., 2011; de Boer and Gudmundsson, 2012). From the LCC perspective, disadvantages of FFP are additional complexity and costs (Klophaus, 2005), e.g. as integration with partner airlines is needed to expand the scope and hence attractiveness of the programme. As a consequence, Ryanair, EasyJet, and Wizz Air still refrain from offering FFP. In MENA, the situation is different as only three airlines have not (yet) introduced loyalty schemes (Flyadeal, Air Cairo and FlyEgypt), while the others are operating simplified frequent flyer programmes - as already suggested as an option for LCCs by Klophaus (2005). Finally, Flydubai is the one and only LCC in MENA which has interlining with its parent company (Emirates).

\section{Barriers to Development}

We close this work in wrapping up key issues for MENA-based LCCs from the literature. Adler and Hashai (2005) or Sørli et al. (2017) regard the Middle East as the center of many national and international conflicts and tensions, which may negatively impact the tourism sector, international trade flows and also incoming foreign direct investments. Examples are the unsolved Israeli-Palestinian conflict, three wars involving Iran and/or Iraq, and the ongoing crises in, e.g., Syria, Libya, Yemen, and Iraq. According to the World Bank (2016) report, 87 million people in four countries (Syria, Libya, Yemen, and Iraq) were directly affected by war in 
2016 which represents almost one-third of the region's population. Consequently, our data analysis shows that despite some $62 \%$ growth in the region's total number of air travel passengers from 2010 to 2018, Syria, Yemen and Libya experienced huge losses in passenger numbers (Syria: $-85 \%$, Libya: $-65 \%$, Yemen: $-99 \%)$ and a complete $(-100 \%)$ reduction in supply by LCCs. Moreover, the interaction between different countries in the region is affected by political tensions like Iran vs. Saudi-Arabia, or UAE, Saudi Arabia, Bahrain and Egypt vs. Qatar. Another issue is missing democracy. The World Bank (2016) expects GDP growth levels (a key driver also for aviation) in MENA to be significantly below the levels that would be achievable if democracy was the prevailing form of Government in the region.

Iran has been involved in different political tensions during the past decades and has experienced significant levels of sanctions. According to Farzanegan and Hayo (2018), after the US's and EU's financial and energy sanctions against Iran in 2012, country's petroleum exports declined from \$114 billion in 2011 to $\$ 61$ billion in 2013 and caused a remarkable reduction in the country's GDP in addition to other barriers such as the reduction in economic exchanges with other countries and the decline in purchasing power of the people. Based on our data analysis, from 2011 to 2014, the number of passengers in the air transport sector in Iran declined by about $60 \%$ from around 13.5 million passengers to less than 8.5 million. After the Iran Nuclear Deal in 2015, which is also known as Joint Comprehensive Plan of Action (JCPOA), a huge number of sanctions against Iran were lifted and Iran experienced a notable increase in the number of passengers in air transport sector until 2018, when the US withdrew from the deal and sanctions were re-introduced. In 2015, the number of air transport passengers was 8.45 million and it almost doubled until 2018 to 16.13 million passengers. The case of Iran clearly shows how political tensions even from countries outside the region can affect the air transport condition in a country.

Also, IATA (2018a) considers geopolitical (in)stabilities as key drivers of change in the aviation industry. According to Dobruszkes (2019), geopolitical issues are a key reason why aircraft do often fly detours - which results in cost increases - and not the shortest possible routes. This is especially true for operational issues in the MENA, such as the above-mentioned airspace ban for Qatar-registered aircraft, and overflight bans for Iran or Syria. 
Schlumberger and Weisskopf (2014) argue that the key to the development of the low-cost business model is the growth and the emergence of the middle-class. The percentage of middle-class people in the region is extremely diverse. According to a benchmark study by Alvaredo et al. (2019), which was based on household surveys, national accounts and income tax and wealth data for the years 2020-2016, the Middle East is the world's most unequal region. The top decile income share in the Middle East region as defined by the authors (Arabian Peninsula, Egypt, Levant (except Cyprus and Israel), Iran, Iraq, Turkey) amounts to $64 \%$, compared to $37 \%$ in Europe, while the bottom $50 \%$ of the population receives just $9 \%$ of total income, compared to $18 \%$ in Europe. The authors argue that the reasons are both inequalities both within the same countries and between countries in the region, especially between oil-rich and population-rich states.

An important driver of aviation growth is liberalization. Despite its nature as a cross-border industry, air transport has traditionally been one of the most heavily regulated sectors (Maertens and Grimme, 2019). One basis for this is the 1944 Chicago Convention in which the signatory states agreed on a framework to maintain the idea of airspace sovereignty but, at the same time, facilitate the inauguration of international air transport linkages. As a consequence, a regime of bilateral air service agreements was introduced according to which states could agree on the allocation of limited traffic rights for bilateral air services (see e.g. Abeyratne, 2013). From the 1970 s to the 1990s, then, air transport in the US and later Europe was subsequently deregulated, and in so-called open sky markets like within the EU (and some neighboring countries) or between the EU and North America airlines can now almost freely select routes, frequencies, and fares, which resulted in more competition, higher efficiency and traffic growth (e.g., Button, 2009).

The literature hardly contains any information on actual air service agreements in the MENA region, or on details like (multiple) designation and capacity or pricing controls. As of now, there is no full open sky across MENA, despite the 1998 "Intra-Arab Freedoms of the Air Programme between the Arab States" and the 2004 "Agreement for the liberalization of air transport between the Arab States" which has - so far - only been ratified by Jordan, Lebanon, Morocco, Oman, Palestine, Syria, Yemen, and the UAE, (AAC, 2017; ICAO, 2009). The 
agreement, which is also referred to as the Damascus Convention, basically foresees liberalization of $1^{\text {st }}$ to $5^{\text {th }}$ freedom traffic (for an overview of the so-called freedoms of the air, see Maertens and Grimme, 2019). For geopolitical reasons, Iran and Israel are not among the signatory states of the Damascus Convention.

In addition, there are some air service agreements at bilateral or multilateral levels with countries within and outside the region. Morrison and Mason (2016) found that, between 2000 and 2014, 63 air service agreements were signed by MENA countries. A very successful example of an Open Skies agreement between a MENA state and the EU is the open skies agreement with Morocco, signed in 2006 as the first aviation agreement of the EU with a country outside of Europe (Schlumberger and Weisskopf, 2012). As an important provision, all carriers in the EU and Morocco may now operate any route between the two regions - without any pricing or capacity restrictions. With a strong presence of LCCs such as Ryanair, EasyJet and Air Arabia Maroc, traffic between the EU and Morocco subsequently increased by $80 \%$ while average fares declined by $60 \%$ (EU, 2020a). Tunisia was the second country that entered negotiations about the comprehensive Euro-Mediterranean agreement with the EU, which was initialed in December 2017 (EU, 2020b). Schlumberger and Weisskopf (2012) argued that such a comprehensive agreement between the EU and Tunisia would have a positive effect on tourism sector of Tunisia and also on the development of the trade and foreign investment.

Against this background, it is expected that any further deregulation will strongly depend on political relaxation in the MENA states, or focus on additional agreements with, e.g., the EU. In this context, also simple horizontal agreements may positively impact air transport, such as between the EU and Lebanon. ${ }^{5}$ As Maertens and Grimme (2019) point out, such agreements provide EU-based (low cost) carriers with more flexibility to also fly from other EU states than their home country to third countries.

Finally, we can identify one framework to be more in favor of LCCs: the non-existence of night curfews at most MENA airports. As a consequence, MENA-based LCCs achieve much higher aircraft utilization than their European counterparts. For instance, average block hours per day

\footnotetext{
${ }^{5}$ See, e.g., https://ec.europa.eu/transport/modes/air/international_aviation/country_index/lebanon_en.
} 
is around 15 hours for Air Arabia $^{6}$ (2016) and 13.3 hours for Flydubai ${ }^{7}$ (2017) compared to just 9.13 for Ryanair ${ }^{8}$ (2018). Other reasons for these long block hours achieved by MENA-based LCC may include longer stage lengths or reduced seasonality.

\section{Summary and Outlook}

This paper assessed the air transport sector in the Middle East and North Africa (MENA) with a special focus on low cost carriers (LCCS). Although this business model is emerging fast, LCC penetration in the MENA market has not yet reached the market share of this business model in pioneer regions like Europe or North America, and market performance differs widely within MENA.

In 2018, 16\% of the MENA market in terms of departing passengers was handled by LCCs, increasing from $10 \%$ in 2010 . The UAE, Saudi Arabia and Morocco are the key markets for LCCs in the region.

Political tensions, regulations and socio-economic frameworks are supposed to play a significant rule here as they directly affect some key perquisites of LCC market entrance, such as demand, air transport liberalization, and geopolitical stability. Extreme examples are the ongoing civil wars in Syria, Yemen, and Libya, where LCCs have completely disappeared while other carriers still operate, albeit at lower levels; sanctions against Iran which prevent aircraft purchase and credit card payments; or the ban of Qatar-bound flights imposed by a number of Gulf countries and Egypt. In addition, there are hardly any liberal open skies agreements in place.

Apart from this, strategic decisions may play a role when it comes to LCC market shares: Qatar, as an oil- and gas-rich country in the region, seems to prefer to focus more on its national flag carrier's operation as a full-network service carrier instead of setting up a LCC. The same applies to Bahrain. On the other hand, the UAE, Oman and Kuwait have actively driven the emergence of the low-cost business model which complements the services of the national full-

\footnotetext{
${ }^{6}$ https://www.airarabia.com/sites/airarabia/files/Air_Arabia_IR_Presentation_Q3_2016.pdf

${ }^{7}$ https://news.flydubai.com/flydubai-sees-strong-growth-in-revenues-record-passengers-and-sustained-profit

${ }^{8}$ https://investor.ryanair.com/wp-content/uploads/2018/07/Ryanair-FY-2018-Annual-Report.pdf
} 
service network carriers (FSNCs) Emirates, Etihad Airways, Oman Air and Kuwait Airways, respectively. Finally, Egypt, Saudi Arabia and Morocco are examples for larger countries where first LCCs have appeared.

The results of this paper further show budget carriers in MENA tend to be positioned more upscale than their European or US counterparts: A benchmarking analysis considering key LCC-

criteria usually referred to in the literature reveals that three carriers follow the "Southwest" approach and five carriers offer additional services and are positioned more like "Jetblue". Interestingly, there is no carrier that follows the LCC fundamentals as strictly as, e.g., Ryanair or Wizz Air.

Further research on the low-cost airlines in the MENA region could, e.g., tackle specific questions like LCC cost structures (in comparison to local FSNC), route profiles of regional LCCS (in contrast to the hub carriers), or the potential of long haul low cost flights from and to MENA. In addition, a more systematic assessment of the actual constraints and barriers to LCCs in the region, e.g. backed by stakeholder interviews, could further enrich the literature.

\section{References}

Abeyratne, R., 2003. The Decision of the European Court of Justice on Open Skies - How Can We Take Liberalization to the Next Level. Journal of Air Law and Commerce 68, 485-518.

Adler, N., Hashai, N., 2005. Effect of open skies in the Middle East region. Transportation Research Part A Policy and Practice 39, 878-894.

Alamdari, F., Fagan, S., 2005. Impact of the adherence to the original low-cost model on the profitability of low-cost airlines. Transport Reviews 25, 377-392.

Alkaabi, K., 2014. Geographies of Middle Eastern Air Transport. In: Goetz, A.R., Budd, L., (Eds), The Geographies of Air Transport. Farnham: Ashgate Publishing Limited, pp. 231- 246.

Alsumairi, M., Tsui, K.W.H., 2017. A case study: The impact of low-cost carriers on inbound tourism of Saudi Arabia. Journal of Air Transport Management 62, 129-145. 
Alvaredo, F., Assouad, L., Piketty, T., 2019. Measuring Inequality in the Middle East 1990-2016:

The World's Most Unequal Region? Review of Income and Wealth 65, 685-711.

Amankwah-Amoah, J., Debrah, Y., 2009. The Emergence of Low-Cost Airlines in Africa: A Preliminary Analysis of Internal and External Drivers. In: Ibeh, K., Davies, S., (Eds), Contemporary Challenges to International Business. Basingstoke: Palgrave Macmillan, pp. 218-231.

Anjos, M., Cheng, R., Currie, C., 2004. Maximizing revenue in the airline industry under one-way pricing. Journal of the Operational Research Society 55), 535-541.

AAC (Arab Air Carriers Organization), 2017. Liberalization (Last updated on 20 April 2017) (https://aaco.org/policy/liberalization).

Boeing, 2018. Commercial Market Outlook 2018-2037

(https://www.boeing.com/resources/boeingdotcom/commercial/market/commercialmarket-outlook/assets/downloads/2018-cmo-07-17.pdf).

Bowen, J., 2019. Low-Cost Carriers in Emerging Countries. $1^{\text {st }}$ edition. Elsevier, Amsterdam and Cambridge (MA).

Button, K., 2009. The impact of US-EU “Open Skies” agreement on airline market structures and airline networks. Journal of Air Transport Management 15, 59-71.

Cento, A., 2009. The airline industry. Physica-Verlag, Heidelberg.

De Boer, E.R., Gudmundsson, S.V., 2012. 30 years of frequent flyer programmes, Journal of Air Transport Management 24, 18-24.

De Wit, J.G., 2014. Unlevel playing field? Ah yes, you mean protectionism. Journal of Air Transport Management 41, 22-29.

Dobruszkes, F., 2013. The geography of European low-cost airline networks: a contemporary analysis. Journal of Transport Geography 28, 75-88. 
Dobruszkes, F., 2019. Why do planes not fly the shortest routes? A review. Applied Geography 109, 102033.

Dobruszkes, F., Wang, J., 2019. Developing a low-cost airline in a semi-protected regime: Comparing China to Europe and the US. Journal of Transport Geography 77, 48-58.

Dresner M., Eroglu C., Hofer C., Mendez F., Tan K., 2015. The impact of Gulf carrier competition on U.S. airlines. Transportation Research Part A: Policy and Practice 79, 31-41.

EU (European Union), 2020a. International aviation: Morocco (https://ec.europa.eu/transport/modes/international-aviation-morocco_en).

EU (European Union), 2020b. International Aviation: Tunisia (https://ec.europa.eu/transport/modes/international-aviation-tunisia_en).

Fageda, X., Suau-Sanchez, P., Mason, K.J., 2015. The evolving low-cost business model: Network implications of fare bundling and connecting flights in Europe. Journal of Air Transport Management 42, 289-296.

Farzanegan, M. and Hayo, B., 2018. Sanctions and the shadow economy: empirical evidence from Iranian provinces. Applied Economics Letters 26, 501-505.

Fiig, T., Isler, K., Hopperstad, C., Belobaba, P., 2009. Optimization of mixed fare structures: Theory and applications. Journal of Revenue and Pricing Management 9, 152-170.

Forsyth, P., 2003. Low-cost carriers in Australia: experiences and impacts. Journal of Air Transport Management 9, 277-284.

Francis, G., Dennis, N., Ison, S., Humphreys, I., 2007. The transferability of the low cost model to longhaul airline operations. Tourism Management 28, 391-398.

Goetz, A.R., Vowles, T.M., 2009. The good, the bad, and the ugly: 30 years of US airline deregulation. Journal of Transport Geography 17, 251-263.

Graf, L., 2005. Incompatibilities of the low-cost and network carrier business models within the same airline grouping. Journal of Air Transport Management 11, 313-327. 
Grimme W., 2011. The growth of Arabian airlines from a German perspective - A study of the impacts of new air services to Asia. Journal of Air Transport Management 17, 333-338.

Hooper, P., Walker, S., Moore, C., Al Zubaidi, Z., 2011. The development of the Gulf region's air transport networks - The first century. Journal of Air Transport Management 17, 325-332.

IATA (International Air Transport Association), 2018a. Future of the airline industry 2035 (https://www.iata.org/contentassets/690df4ddf39b47b5a075bb5dff30e1d8/iata-futureairline-industry-pdf.pdf)

IATA (International Air Transport Association), 2018b. Strengthening Aviation Benefits in MENA (https://www.iata.org/en/pressroom/pr/2018-11-06-01/).

ICAO (International Civil Aviation Organization), 2009. Regional / Plurilateral Agreements and Arrangements for Liberalization (https://www.icao.int/sustainability/Compendium/Documents/RegionalAgreements.pdf).

Kachaner, N., Lindgardt, Z., Michael, D., 2011. Innovating low-cost business models. Strategy \& Leadership 39, 43-48.

Klophaus, R., 2005. Frequent flyer programmes for European low-cost airlines: Prospects, risks and implementation guidelines. Journal of Air Transport Management 11, 348-353.

Klophaus, R., Conrady, R., Fichert, F., 2012. Low cost carriers going hybrid: evidence from Europe. Journal of Air Transport Management 23, 54-58.

Klophaus, R., Fichert, F., 2019. From Low-cost Carriers to Network Carriers without Legacy? Evolving Airline Business Models in Europe. In: Cullinane, K. (Ed), Airline Economics in Europe, Bingley: Emerald, pp. 57-75.

Lawton, T., 2002. Cleared for Take-Off: Structure and Strategy in the Low-fare Airline Business. Routledge.

Lohmann, G., Koo, T.T.R., 2013. The airline business model spectrum. Journal of Air Transport Management 31, 7-9. 
Lordan, O., 2014. Study of the Full-service and Low-cost Carriers Network Configuration. Journal of Industrial Engineering and Management 7, 1112-1123.

Maertens, S., 2018. A metric to assess the competitive position of airlines and airline groups in the intra-European air transport market. Research in Transportation Economics 72, 65-73.

Maertens, S., Grimme, W., 2019. Traffic impacts of EU horizontal air service agreements. Transportation Research Procedia 37, 290-297.

Martín, J.C., Román, C., Espino, R., 2011. Evaluating frequent flyer programmes from the air passengers' perspective. Journal of Air Transport Management 17, 364-368.

Mason, K.J., Morrison, W.G., 2008. Towards a means of consistently comparing airline business models with an application to the 'low-cost' airline sector. Research in Transportation Economics 24, 75-84.

Morrison, W.G., Mason, K.J., 2016. Low cost carriers in the Middle East and North Africa: Prospects and strategies. Research in Transportation Business and Management 21, 54-67.

Neal, Z., Kassens-Noor, E., 2011. The business passenger niche: Comparing legacy carriers and Southwest during a national recession. Journal of Air Transport Management 17, 231-232.

Njoya, E., 2016. Africa's single aviation market: The progress so far. Journal of Transport Geography 50, 4-11.

O'Connell, J.F., 2011. The rise of the Arabian Gulf carriers: An insight into the business model of Emirates Airline. Journal of Air Transport Management 17, 339-346.

Pirie, G., 2014. Geographies of Air Transport in Africa: Aviation's 'Last Frontier'. In: Goetz, A.R., Budd, L., (Eds), The Geographies of Air Transport. Farnham: Ashgate Publishing Limited, pp. 247-266.

Sabre, 2014. Sabre AirVision Market Intelligence, Version 5.7. User Guide. 
Schlumberger, Charles E., and Weisskopf, N., 2012. Open Skies in North Africa: Is Tunisia the Next Morocco? European Institute of the Mediterranean, Barcelona, Spain. IEMed Mediterranean Yearbook Med. 2012, 247-253.

Schlumberger, C. E., Weisskopf, N., 2014. Ready for Takeoff? The Potential for Low-cost Carriers in Developing Countries. Directions in development, Infrastructure. 90586. World Bank Group (https://elibrary.worldbank.org/doi/pdf/10.1596/978-1-4648-0282-9).

Sørli, M., Gleditsch, N. and Strand, H., 2005. Why Is There So Much Conflict in the Middle East? Journal of Conflict Resolution 49, 141-165.

Taumoepeau, S., Towner, N., Losekoot, E., 2017. Low-Cost Carriers in Oceania, Pacific: Challenges and opportunities. Journal of Air Transport Management 65, 40-42.

Vespermann, J., Wald, A., Gleich, R., 2008. Aviation growth in the Middle East - impacts on incumbent players and potential strategic reactions. Journal of Transport Geography 16, 388-394.

Vidović, A., Štimac, I., Vince, D., 2013. Development of business models of low-cost airlines. International Journal for Traffic and Transport Engineering 3, 69-81.

World Bank, 2016. By the Numbers: The Cost of War \& Peace in the Middle East (https://www.worldbank.org/en/news/feature/2016/02/03/by-the-numbers-the-cost-ofwar-and-peace-in-mena).

Zhang, A., Hanaoka, S., Inamura, H., Ishikura, T., 2008. Low-cost carriers in Asia: Deregulation, regional liberalization and secondary airports. Research in Transportation Economics 24, 3650. 
Annex 1: Departing passenger numbers (in Million), country level, 2010-2018.

\begin{tabular}{|c|c|c|c|c|c|c|c|c|c|c|}
\hline Year & 2010 & 2011 & 2012 & 2013 & 2014 & 2015 & 2016 & 2017 & 2018 & $\begin{array}{l}\text { Growth } \\
\text { 2010-2018 }\end{array}$ \\
\hline UNITED ARAB EMIRATES & 31.94 & 34.61 & 39.33 & 45.64 & 49.96 & 56.01 & 60.37 & 61.21 & 60.36 & $89 \%$ \\
\hline SAUDI ARABIA & 21.56 & 24.25 & 25.99 & 29.77 & 34.35 & 35.93 & 39.69 & 44.31 & 48.55 & $125 \%$ \\
\hline QATAR & 7.99 & 9.06 & 10.53 & 11.52 & 13.08 & 15.24 & 18.20 & 17.40 & 17.00 & $113 \%$ \\
\hline IRAN & 13.68 & 13.32 & 11.63 & 10.73 & 8.31 & 8.45 & 11.33 & 11.88 & 16.13 & $18 \%$ \\
\hline EGYPT & 15.26 & 10.93 & 12.37 & 11.77 & 12.38 & 13.00 & 11.74 & 12.77 & 14.59 & $-4 \%$ \\
\hline ISRAEL & 6.22 & 6.79 & 6.91 & 7.36 & 8.01 & 8.41 & 8.56 & 9.73 & 11.42 & $84 \%$ \\
\hline MOROCCO & 8.04 & 8.13 & 7.55 & 8.37 & 8.70 & 8.64 & 8.96 & 10.18 & 11.34 & $41 \%$ \\
\hline OMAN & 3.23 & 3.26 & 3.74 & 4.38 & 4.58 & 5.42 & 6.21 & 7.19 & 7.81 & $142 \%$ \\
\hline KUWAIT & 4.51 & 4.21 & 4.40 & 4.66 & 5.17 & 5.66 & 6.02 & 6.86 & 7.51 & $67 \%$ \\
\hline ALGERIA & 4.40 & 4.33 & 3.79 & 4.64 & 5.08 & 5.48 & 6.93 & 7.41 & 7.12 & $62 \%$ \\
\hline TUNISIA & 4.35 & 3.29 & 4.40 & 4.26 & 4.08 & 3.19 & 3.30 & 3.94 & 4.50 & $3 \%$ \\
\hline BAHRAIN & 4.84 & 4.17 & 4.31 & 3.55 & 3.81 & 4.08 & 4.17 & 4.11 & 4.39 & $-9 \%$ \\
\hline IRAQ & 0.59 & 0.63 & 1.14 & 2.05 & 1.68 & 1.98 & 3.28 & 4.28 & 4.31 & $634 \%$ \\
\hline JORDAN & 2.86 & 2.94 & 3.15 & 3.35 & 3.56 & 3.32 & 3.52 & 3.76 & 4.12 & $44 \%$ \\
\hline LEBANON & 2.63 & 2.69 & 2.86 & 3.00 & 3.04 & 3.41 & 3.57 & 4.04 & 4.11 & $56 \%$ \\
\hline LIBYA & 2.75 & 1.50 & 1.87 & 2.73 & 1.84 & 0.84 & 1.17 & 1.07 & 0.98 & $-65 \%$ \\
\hline SYRIAN ARAB REPUBLIC & 2.26 & 2.11 & 1.12 & 0.25 & 0.02 & 0.12 & 0.14 & 0.27 & 0.35 & $-85 \%$ \\
\hline YEMEN & 1.58 & 1.33 & 1.33 & 1.47 & 1.53 & 0.47 & 0.00 & 0.00 & 0.01 & $-99 \%$ \\
\hline PALESTINE & 0.00 & 0.00 & 0.00 & 0.00 & 0.00 & 0.00 & 0.00 & 0.00 & 0.00 & \\
\hline Total & 138.68 & 137.56 & 146.44 & 159.49 & 169.19 & 179.64 & 197.19 & 210.41 & 224.60 & $62 \%$ \\
\hline
\end{tabular}

Source: Sabre MI

Annex 2: Departing low cost passenger numbers (in Million), country level, 2010-2018.

\begin{tabular}{|l|l|l|l|l|l|l|l|l|l|l|}
\hline & $\mathbf{2 0 1 0}$ & $\mathbf{2 0 1 1}$ & $\mathbf{2 0 1 2}$ & $\mathbf{2 0 1 3}$ & $\mathbf{2 0 1 4}$ & $\mathbf{2 0 1 5}$ & $\mathbf{2 0 1 6}$ & $\mathbf{2 0 1 7}$ & $\mathbf{2 0 1 8}$ & Growth 2010-2018 \\
\hline UNITED ARAB EMIRATES & 3.81 & 4.91 & 6.12 & 7.60 & 8.36 & 9.82 & 10.67 & 10.72 & 10.42 & $173 \%$ \\
\hline SAUDI ARABIA & 2.83 & 2.50 & 3.27 & 4.76 & 6.02 & 6.97 & 8.47 & 9.17 & 11.28 & $298 \%$ \\
\hline QATAR & 0.36 & 0.40 & 0.45 & 0.58 & 0.66 & 0.72 & 0.77 & 0.39 & 0.18 & $-50 \%$ \\
\hline IRAN & 0.10 & 0.11 & 0.14 & 0.12 & 0.17 & 0.44 & 0.51 & 0.56 & 0.37 & $281 \%$ \\
\hline EGYPT & 0.91 & 1.00 & 1.02 & 1.03 & 1.04 & 1.20 & 1.43 & 1.77 & 2.28 & $150 \%$ \\
\hline ISRAEL & 0.10 & 0.18 & 0.24 & 0.41 & 0.68 & 0.85 & 1.02 & 1.43 & 2.09 & $1895 \%$ \\
\hline MOROCCO & 2.43 & 2.72 & 1.95 & 2.48 & 2.65 & 2.78 & 2.74 & 3.25 & 4.04 & $67 \%$ \\
\hline OMAN & 0.18 & 0.25 & 0.27 & 0.34 & 0.41 & 0.53 & 0.57 & 0.92 & 0.96 & $449 \%$ \\
\hline KUWAIT & 1.13 & 1.05 & 1.15 & 1.31 & 1.48 & 1.58 & 1.65 & 1.64 & 1.99 & $76 \%$ \\
\hline ALGERIA & 0.00 & 0.00 & 0.00 & 0.02 & 0.04 & 0.08 & 0.13 & 0.19 & 0.22 & n/a \\
\hline TUNISIA & 0.20 & 0.15 & 0.17 & 0.17 & 0.23 & 0.27 & 0.25 & 0.25 & 0.30 & $48 \%$ \\
\hline BAHRAIN & 0.73 & 0.29 & 0.30 & 0.32 & 0.35 & 0.40 & 0.47 & 0.48 & 0.48 & $-33 \%$ \\
\hline
\end{tabular}




\begin{tabular}{|l|l|l|l|l|l|l|l|l|l|l|}
\hline IRAQ & 0.04 & 0.07 & 0.23 & 0.34 & 0.31 & 0.40 & 0.51 & 0.47 & 0.49 & $1047 \%$ \\
\hline JORDAN & 0.22 & 0.28 & 0.28 & 0.36 & 0.48 & 0.50 & 0.54 & 0.61 & 0.69 & $213 \%$ \\
\hline LEBANON & 0.36 & 0.41 & 0.40 & 0.40 & 0.36 & 0.37 & 0.37 & 0.40 & 0.43 & $20 \%$ \\
\hline LIBYA & 0.00 & 0.00 & 0.00 & 0.00 & 0.00 & 0.00 & 0.00 & 0.00 & 0.00 & $-100 \%$ \\
\hline SYRIAN ARAB REPUBLIC & 0.46 & 0.45 & 0.23 & 0.01 & 0.00 & 0.00 & 0.00 & 0.00 & 0.00 & $-100 \%$ \\
\hline YEMEN & 0.05 & 0.02 & 0.04 & 0.05 & 0.04 & 0.01 & 0.00 & 0.00 & 0.00 & $-100 \%$ \\
\hline PALESTINE & 0.00 & 0.00 & 0.00 & 0.00 & 0.00 & 0.00 & 0.00 & 0.00 & 0.00 & n/a \\
\hline Total & 13.91 & 14.78 & 16.28 & 20.28 & 23.29 & 26.92 & 30.11 & 32.23 & 36.22 & $160 \%$ \\
\hline
\end{tabular}

Source: Sabre MI 